\title{
EHMTI-0386. Chronic subdural hematoma and spinal cerebrospinal fluid leak and in non- geriatric patients
}

\author{
J Beck ${ }^{1 *}$, CT Ulrich ${ }^{1}$, J Gralla ${ }^{2}$, J Fichtner ${ }^{1}$, C Fung ${ }^{1}$, W Z'Graggen², A Raabe ${ }^{1}$ \\ From 4th European Headache and Migraine Trust International Congress: EHMTIC 2014 \\ Copenhagen, Denmark. 18-21 September 2014
}

\section{Introduction}

The etiology of chronic subdural hematoma (cSDH) in non-geriatric patients ( $\leq 60$ years) often remains unclear.

\begin{abstract}
Aim
The primary objective of this study was to identify spinal cerebrospinal fluid (CSF) leaks in non-geriatric patients with the hypothesis that spinal CSF leaks are causally related to cSDH.
\end{abstract}

\section{Methods}

All consecutive patients $\leq 60$ years who were operated upon for cSDH from Sept. 2009 to April 2011 were included in this prospective cohort study. The patient workup included an extended search for a spinal CSF leak using a systematic algorithm: magnetic resonance (MR) imaging of the spinal axis with or without intrathecal contrast application, myelography/fluoroscopy, and postmyelography CT scanning. Spinal pathologies were classified according to direct proof of CSF outflow from intra- to extrathecal space, presence of extrathecal fluid accumulation, presence of spinal meningeal cysts, or no pathological findings.

\section{Results}

Twenty-seven patients (mean age \pm SD: $49.6 \pm 9.2$ years) were operated upon for cSDH. The chief complaint was headache in $15(56 \%)$ patients. Hematomas were unilateral in 20 and bilateral in seven. In seven of 27 patients (25.9\%) spinal CSF leakage was proven, in nine (33.3\%) patients spinal meningeal cysts in the cervico-thoracic region were found, and three (11.1\%) had spinal cysts in the sacral

${ }^{1}$ Neurosurgery, Inselspital, Bern, Switzerland

Full list of author information is available at the end of the article region. The remaining eight (29.6\%) patients showed no pathological findings.

\section{Conclusions}

Spinal imaging results are challenging the pathogenetic concept of $\mathrm{CSDH}$ in young patients. The direct proof of spinal CSF leakage in $25.9 \%$ of patients suggests that spinal CSF leaks may be a frequent cause of non-geriatric cSDH.

No conflict of interest.

\section{Authors' details}

${ }^{1}$ Neurosurgery, Inselspital, Bern, Switzerland. ${ }^{2}$ Neuroradiology, Inselspital, Bern, Switzerland.

Published: 18 September 2014

doi:10.1186/1129-2377-15-S1-J16

Cite this article as: Beck et al:: EHMTI-0386. Chronic subdural hematoma and spinal cerebrospinal fluid leak and in non-geriatric patients. The Journal of Headache and Pain 2014 15(Suppl 1):J16.

Submit your manuscript to a SpringerOpen ${ }^{\odot}$ journal and benefit from:

- Convenient online submission

- Rigorous peer review

- Immediate publication on acceptance

- Open access: articles freely available online

- High visibility within the field

- Retaining the copyright to your article

Submit your next manuscript at $>$ springeropen.com (c) 2014 Beck et al; licensee Springer. This is an Open Access article distributed under the terms of the Creative Commons Attribution License (http://creativecommons.org/licenses/by/2.0), which permits unrestricted use, distribution, and reproduction in any medium, provided the original work is properly cited. 